\section{Influence of Resin Cements on the Tension Force of Cast Frameworks Made by the Technique of Framework Cemented on Prepared Abutments}

\author{
Ana Paula Perroni ${ }^{1}$, Érica Alves Gomes ${ }^{1}$, Amália Machado Bielemann ${ }^{1}$, Bruna \\ Baseggio1, Leonardo Federizzi', Aloísio Oro Spazzin1, Mateus Bertolini \\ Fernandes dos Santos 2
}

\author{
'Department of Prosthodontics and \\ Dental Materials, Dental School, IMED \\ - Universidade Meridional, Passo \\ Fundo, RS, Brazil \\ ${ }^{2}$ UFPEL - Federal University of \\ Pelotas, Pelotas, RS, Brazil \\ Correspondence: Profa. Dra. Érica \\ Alves Gomes, Rua Alcidia Proença \\ Pizani, 280, 14110-000, Ribeirão Preto, \\ SP, Brasil. Tel: + 55-16-99785-2704. \\ e-mail: ericaagomes@yahoo.com.br
}

\begin{abstract}
This study evaluated the tension force of cast frameworks made by the technique of framework cemented on prepared abutments using two different resin cements. Forty multi-unit abutment analogs were individually fixed with chemically cured acrylic resin inside PVC cylinders using a parallelometer. Brass cylindrical abutments were tightened to the multi-unit abutments to be used as spacers and then castable UCLA abutments were positioned above. These abutments were cast with $\mathrm{Ni}-\mathrm{Cr}$ and then divided into 4 groups $(n=10)$ : cemented with RelyX $U 100^{\circledR}$; cemented with RelyX $U 100^{\circledR}$ and simulation of acrylic resin polymerization process; cemented with Multilink ${ }^{\circledR}$; and cemented with Multilink ${ }^{\circledR}$ and simulation of acrylic resin polymerization process. Abutments were cemented according to manufacturers' instructions. In a universal testing machine, tensile strength was applied in the direction of the long axis of the abutments at $1 \mathrm{~mm} / \mathrm{min}$ crosshead speed until displacement of the luted abutments was obtained. The values of maximum tensile force $(\mathrm{N})$ required for the displacement of the luted abutments were tabulated and analyzed statistically by one-way ANOVA with a 95\% confidence level. No statistically significant difference was found among the groups $(p>0.05)$. There was an increase in mean tension force when the specimens were subjected to the simulation of acrylic resin polymerization process, but the results did not differ statistically. Both resin cements presented positive results as regards the retention of luted abutments on their respective multi-unit abutments. Both materials may be indicated for the technique of framework cemented on prepared abutments when professionals pursuit better adaptation of implant-supported frameworks.
\end{abstract}

Key Words: adaptation, biomechanics, dental implants, resin cements.

\section{Introduction}

Long-term success with implant-supported prosthesis is influenced by several factors. Among them is the perfect adaptation between the prosthetic abutments and the implants, to be obtained during the prosthesis manufacture in order to avoid the occurrence of excessive stress and strains on the peri-implant bone tissue and prosthetic components that could result in biological or mechanical complications $(1,2)$.

Perfect adaptation of the prosthetic components, also known as passive fit, is assumed to be one of the most significant prerequisites for the maintenance of the bone-implant interface $(3,4)$. The adaptation of implant frameworks is determined by fabrication process and it could be jeopardized at any step of the entire clinical and laboratory procedures $(5,6)$. The framework cemented on prepared abutments technique is based on the compensation of the shrinkage or deformation produced by casting (7). To do so, a prosthetic framework is first waxed and cast over cylindrical abutments. After finishing and polishing procedures, the framework is luted to these abutments on an index cast using resin cement, and the framework and abutments assembly are tightened to the implants as a screw-retained prosthesis. The advantage of this technique is that the cylindrical abutments screwed to the implants are made by CAD/CAM, which presents a high level of adaptation, and the distortion originated by the framework casting is compensated by the resin cement layer, providing a more passive fit (1) and reducing cost and chair time (6).

A recent study presented a 2-year follow up clinical case using the technique of framework cemented on prepared abutment (6). However, little is known about the use of different resin cements and the tensile force that could result in failure due to loosening or separation of the abutments. Thus, careful consideration on the choice of cement should be exercised when cementing metallic components, since the polymerization will depend on chemical activation only. Since the prosthetic framework will be retained by the luting agent, it is important to select a resin cement that provides adequate retention to the system. Thus, the aim of this study was to evaluate 
the tension force of cast frameworks luted to titanium cylindrical abutments using two different resin cements. The tested hypotheses were that: 1) the curing modes of the resin cements and 2) the acrylic resin polymerization process affect the tension force of frameworks.

\section{Material and Methods}

\section{Specimens}

Forty implant analogs of multi-unit abutments (Neodent Implante Osteointegrável, Curitiba, PR, Brazil) were individually fixed with chemically cured acrylic resin into PVC cylinders using a parallelometer. Brass cylindrical abutments (Neodent Implante Osteointegrável) were tightened to the multi-unit abutments to be used as spacers and then castable UCLA abutments were positioned above it and a loop wax-up was created to the occlusal surface of abutment to allow for tension force testing $(8,9)$. These abutments were cast with $\mathrm{Ni}-\mathrm{Cr}$ alloy and their inner surfaces were blasted with aluminum oxide (50 $\mathrm{m \mu}, 80$ psi). The cast abutments were divided into 4 groups $(n=10)$ : cemented with RelyX U100; cemented with RelyX U100 and simulation of acrylic resin polymerization process; cemented with Multilink; and cemented with Multilink and simulation of acrylic resin polymerization process. The cements were mixed according to manufacturers' recommendations. Abutments were cemented with a $5 \mathrm{~kg}$ load directed down the long axis (10).

\section{Tension Force Evaluation}

Mechanical tensile strength was applied in a universal testing machine Versat 502 (Panambra Indústria e Técnica S.A., São Paulo, SP, Brazil) in the direction of the long axis of the analogs at $1 \mathrm{~mm} / \mathrm{min}$ crosshead speed until displacement of the luted abutment. A computer attached to the machine recorded the values. The values of the maximum tensile force $(\mathrm{N})$ required for displacement of the luted abutments were tabulated and statistically analyzed by one-way ANOVA with a 95\% confidence level.

\section{Results}

The tension force values required to displace the luted

Table 1. Tension force means (N), standard deviation (SD), and confidence interval (Cl) for each group

\begin{tabular}{lcc}
\hline Group & Means (SD) & $\mathrm{Cl}$ \\
\hline RelyX U100 & $870.1(77.86)$ & \pm 48.26 \\
RelyX U100+polymerization & $949.5(126.49)$ & \pm 78.40 \\
Multilink & $870.4(107.04)$ & \pm 66.34 \\
Multilink+polymerization & $873.5(108.10)$ & \pm 67.00 \\
\hline
\end{tabular}

abutments are shown in Table 1. The dual cure resin cement (RelyXU100) showed higher mean values compared with the cement with chemical polymerization (Multilink). However, no statistically significant difference between groups was found ( $p>0.05$ ). In addition, there was an increase in the mean tension force values when the specimens were subjected to the simulation of acrylic resin polymerization process, but these results also did not differ statistically.

\section{Discussion}

The hypotheses tested in the present study were both rejected because no statistically significant difference was observed between the used different resin cements or the simulation of acrylic resin polymerization process. The similar bond strength values obtained for both resin cements could be attributed to the good mechanical properties of the resin cements, that have a combination of high flexural strength and high modulus of elasticity (11). The adhesive capabilities obtained by means of bonding procedures also make the resin cements a good option to be used in the framework cemented on prepared abutments technique. The simulation of acrylic resin polymerization process did not influence the tensile strength to displace the luted abutments for both the cement types, which could be interpreted as an important finding, since after the acrylic resin application the frameworks made by the present technique will not be negatively influenced in the retention of cast abutments on their respective multi-unit abutments.

Both resin cements evaluated in this study presented positive results as regards the retention of the cast abutments on their respective multi-unit abutments. Thus, these materials may be indicated for the technique of framework cemented on prepared abutments when the professional demands a better adaptation of implantsupported prosthesis frameworks.

It is important to mention that there are other methods that could be used to improve the adaptation of one-piece casted frameworks, such as electroerosion and laser welding $(12,13)$. These techniques are widely used and their effectiveness on improving fit of implant frameworks has been demonstrated. However, the need of expensive equipment (electroerosion and laser welding machines) reduces the possibility of large-scale use of such techniques. On the other hand, the technique of framework cemented on prepared abutments does not require special equipment and is also less sensitive to operator skills than laser welding.

Further studies on this technique should be performed in order to compare the improvement of fit using this and other techniques, and to evaluate clinically its long-term success. 


\section{Resumo}

Este estudo avaliou a força de tração de infraestruturas fundidas confeccionadas pela técnica da infraestrutura cimentada sobre pilares preparados utilizando dois diferentes cimentos resinosos. Quarenta análogos de pilares multi-unit foram individualmente fixados com resina acrílica quimicamente ativada em cilindros de PVC utilizando um delineador. Pilares cilíndricos foram torqueados aos pilares multi-unit para serem usados como espaçadores e, então, pilares calcináveis UCLA foram posicionados sobre eles. Estes pilares foram fundidos em liga de $\mathrm{Ni}-\mathrm{Cr}$ e divididos em 4 grupos $(\mathrm{n}=10)$ : cimentados com RelyX U100 ${ }^{\circledR}$; cimentados com RelyXU100 ${ }^{\circledR}$ e simulação do processo de polimerização da resina acrílica; cimentados com Multilink ${ }^{\circledR}$; e cimentados com Multilink ${ }^{\circledR}$ e simulação do processo de polimerização da resina acrilica. Os pilares foram cimentados de acordo com as recomendações dos fabricantes. Em máquina universal de ensaio, a resistência à tração foi aplicada na direção do longo eixo dos pilares a uma velocidade de $1 \mathrm{~mm} / \mathrm{min}$ até o deslocamento do pilar cimentado ser obtido. Os valores da tração máxima $(\mathrm{N})$ necessária para o deslocamento dos pilares cimentados foram tabulados e analisados estatisticamente pela ANOVA de 1 fator com 95\% de nivel de confiança. Diferença estatisticamente significativa não foi encontrada entre os grupos $(p>0,05)$. Houve um aumento na força média de tração quando os espécimes foram submetidos à simulação de processo de polimerização da resina acrílica, mas os resultados não diferiram estatisticamente. Ambos os cimentos resinosos apresentaram resultados positivos no que diz respeito à retenção dos pilares cimentados em seus respectivos pilares multi-unit. Ambos os materiais podem ser indicados para a técnica da infraestrutura cimentada sobre pilares preparados quando os profissionais buscam melhor adaptação de infraestruturas de

\section{References}

1. Buzayan MM, Yunus NB. Passive fit in screw retained multi-unit implant prosthesis understanding and achieving: a review of the literature. J Indian Prosthodont Soc 2014;14:16-23.
2. Kan JY, Rungcharassaeng K, Bohsali K, Goodacre CJ, Lang BR. Clinical methods for evaluating implant framework fit. J Prosthet Dent 1999;81:7-13.

3. Sahin $\mathrm{S}$, Cehreli MC. The significance of passive framework fit in implant prosthodontics: current status. Implant Dent 2001;10:85-92.

4. Branemark PI. Osseointegration and its experimental background. J Prosthet Dent 1983;50:399-410.

5. Greven B, Luepke $\mathrm{M}$, von Dorsche SH. Telescoping implant prostheses with intraoral luted galvano mesostructures to improve passive fit. J Prosthet Dent 2007;98:239-244.

6. Spazzin AO, Spazzin WO, Schuh C, Bacchi A, Tosta VB, Marcaccini AM. Technique of framework cemented on prepared abutments to obtain passive fit at fixed complete denture: a 2-year follow-up report. Braz Dent J 2014;25:565-570.

7. Aparicio C. A new method to routinely achieve passive fit of ceramometal prostheses over Branemark osseointegrated implants: a two-year report. Int J Periodontics Restorative Dent 1994;14:404-419.

8. Breeding LC, Dixon DL, Bogacki MT, Tietge JD. Use of luting agents with an implant system: Part I. J Prosthet Dent 1992;68:737-741.

9. Dixon DL, Breeding LC, Lilly KR. Use of luting agents with an implant system: Part II. J Prosthet Dent 1992;68:885-890.

10. Mansour A, Ercoli C, Graser G, Tallents R, Moss M. Comparative evaluation of casting retention using the ITI solid abutment with six cements. Clin Oral Implants Res 2002;13:343-348.

11. Attar $N, T a m L E, M c C o m b D$. Mechanical and physical properties of contemporary dental luting agents. J Prosthet Dent 2003;89:127-134.

12. Tiossi R, Falcao-Filho HB, Aguiar FA, Jr., Rodrigues RC, Mattos MG, Ribeiro RF. Prosthetic misfit of implant-supported prosthesis obtained by an alternative section method. J Adv Prosthodont 2012;4:89-92.

13. Silva $T B$, Arruda Nobilo MA, Pessanha Henriques GE, Mesquita MF, Guimaraes MB. Influence of laser-welding and electroerosion on passive fit of implant-supported prosthesis. Stomatologija 2008;10:96100.

Received February 18, 2014 Accepted March 12, 2015 